\title{
DISCOVERING EFL LEARNERS' PREFERENCES TOWARD PRONUNCIATION PRACTICE CLASS
}

\author{
Abdul Rosyid ${ }^{a *}$, Deddy Sofyan ${ }^{a}$ ) \\ ${ }^{a)}$ Universitas Pakuan, Bogor, Indonesia \\ ${ }^{*}$ Corresponding Author: abdulrosyid@ unpak.ac.id
}

Article history: received 30 January 2020; revised 19 February 2020; accepted 19 February 2020

\begin{abstract}
This following study is an effort to discover students' preferences toward pronunciation practice class. The method used was survey method. The sample of this research was the second semester students of English Education Study Program, Faculty of Teacher Training and Educational Sciences, Pakuan University. The data was gathered through questionnaire administered online. Having analyzed the questionnaire, there are three important findings. The first one dealing with students' opinion related to the materials given in pronunciation classroom. It was discovered that almost all of the students are in the positive side dealing with the issue. The pronunciation materials that the students agree to be maintained are focusing on segmental and suprasegmental of pronunciation. The second findings related to the students' opinion about pronunciation teaching and learning process. It was found out that the students prefer to learn pronunciation material through real practice activities; such as reading aloud, listening English songs, watching English videos and interacting with native speakers. The final point addressed students' preferences toward pronunciation materials. The materials that have been discussed so far are the materials that they like and meet their need. The materials are related with vowels, consonants, diphthongs, lingking sounds, intonation, and stress. There is also interesting finding related to the materials that the students want to learn. English around the world, pronuncing English slang and online application for learning pronunciation are three novel materials that students want to study
\end{abstract}

Keywords: Students' Preferences, Pronunciation Practice Class.

\section{INTRODUCTION}

The ability to investigate students' need regarding the materials to learn and to discuss is deeply important to master by teachers. Since the teachers are the one who will face the students in the classroom, it indicates that the teachers should know exactly about everything regarding their students. However, developing curriculum is not an easy thing to do, there are some steps need to be conducted. Unfortunately, some teachers, nowadays, have no any knowledge about how to do the process. Hence, through this research, the writers would like to write down about the steps in developing curriculum. The focus will be on designing curriculum for Pronunciation Practice. The writers choose this subject because of getting inspired by the following statement; "A consideration of learners' pronunciation error and of how these can inhibit successful communication is a useful basis on which to asses why it is important to deal with pronunciation in the classroom"[1]. It can be said that pronunciation is one of important language components that needs to be developed in order to succeed the process of oral communication.

The steps in running the process will be started by developing needs analysis, formulating goals and objectives based on the information gathered from previous step and then designing material regarding the result from two steps in advance. The steps will be explained in detail and based on theory from Brown [2] and Tomlinson [3].

Based on the background of the study elaborated in advance, one problem that the researchers want to address is 'what are the students' preferences for pronunciation practice materials?'

\section{RESEARCH METHODS}

Along three to four months, several procedures are conducted in order to gather the data needed and to answer the research questions of this study. The procedures of this research were based on the steps in conduting need analysis design based on scholars mentioned in advance. Here are the following procedures:

1. Making basic decision about the need analysis

In this step, the researchers made decision regarding who will be involved in this study, what information will be gathered and choosing dichotomy in sifting process.

2. Gathering information

In this second step, the researchers designed types of quetions gathered to the participants through online survey. The questions focused on investigating students' prefferences toward pronunciation materials.

3. Using the information

The next activity was analyzing and using the information. Since the main purpose of this needs analysis process is producing, at least, group of topics or materials for pronunciation practice based on the information gathered.

In order to carry out this research, closed quetionnaire consisting of 19 questions was designed and administered using online survey. The statements in the questionnaires 
used Bahasa Indonesia in order to avoid missunderstanding. Likert scale was used with four options; sangat setuju, setuju, tidak setuju, sangat tidak setuju. The indicators of this questionare are intended to meet the research question, they are:

1. Students' opinion related to the materials given in pronunciation class

2. Students' opinion related to the teaching and learning process in pronunciation class

3. Students' preference related to the materials in pronunciation class.

All of the statements in the qustionnaire are derived fro the theories and previous studies.

\section{RESULTS AND DISCUSSION}

\section{Students' Opinion Related to the Materials Given in Pronunciation Class}

As it was explained in advance, the data gathered in this research was only through online survey in a form of closed questionnaire focusing on three different indicators.

The findings regarding students' perspective toward the materials that they have got in pronunciation class. There are two focusses dealing with pronunciation materials; segmental and suprasegmental phonemes (Hancokc [4,5]). The former deals with vowels, diphthongs and consonants sounds, while the latter deals with sentences focusing on stress and intonation. The finding displayed discovered that all participants are in positive agreement with the statements. Though, it was also found that 5,6\% of the total participants are in negative position dealing with learning English sounds specifically. It also happened in the area of remembering phonetic symbols to help them reading a new word; learning the theory of stress and intonation; discussing how to read sentences by paying attention on rising and falling intonation. $1.4 \%$ to $1.5 \%$ of the participants seemed uninterested to learn about those materials. All in all, almost all of participants have similar perspective toward the need and the cornerstone of learning aforementioned pronunciation materials. The following are the pronunciation materials that the participants agree to be maintained in learning English pronunciation:

1. Speech Organs Used in Pronouncing Words

2. Definition of English Sounds (Vowels, Diphthongs, Consonants)

3. How to Produce English Sounds (Vowels, Diphthongs and Consonants) by Using Phonemic Symbols

4. Minimal Pairs

5. Stress, Rising and Falling Intonation

6. Linking sounds, contracted forms, leaving out consonants, fast and careful speech, dividing speech into small units

\section{Students' Opinion Related to the Teaching and Learning Process in Pronunciation Class}

Related to the second indicator, five different statements were designed and the result showed that $98 \%$ of the participants love learning pronunciation through reading words and sentences repeatedly. Other activities that become the participants 'favorite to be applied in practicing pronunciation following by the number of the percentage are as follow:

1. Creating sentences and dialogues consisting of certain sounds being discussed and acting it out (91.6\%). (Murcia, et.al [5])

2. Listening to the English songs, watching videos used English language or completed with English subtitles, and imitating the pronunciation $(98.6 \%)$. (Cheng: 1998; Griffth, et.al. [6,7])

3. Looking up printed dictionary to check how to pronounce the words $(95.7 \%)$.

4. Interacting with native speakers directly $(94.4 \%)$.

From the data above, it can be summed up that the favorite activities applied in learning pronunciation can be classified into two different categories; they are receiving information dealing with how to pronounce the words and practicing pronunciation through oral activities. The most favorite one is learning pronunciation through songs or movies. This one is actually one of activities suggested by Cheng [6]. However, it also needs more in-depth research to find out the causes of why some participants do not prefer learning pronunciation through suggested activities mentioned above.

\section{Students' Preference Related to the Materials in Pronunciation Class}

In order to gather the data regarding this indicator and to support the previous indicators, four different statements were designed.

To support the data related to this indicator, the researchers posted one open statement to the participants. The statement was 'Saya sangat tertarik mempelajari English pronunciation dalam hal.... The following are the example of responses got from the participants:

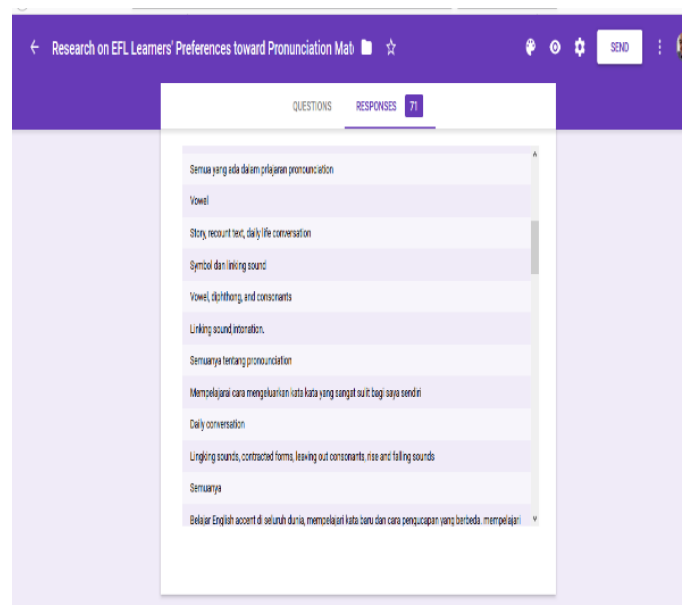

Figure 1. Example of Questionnaire Administered Online 
From four closed statements on one open statement, it can be categorized the students' preference toward pronunciation materials. The following are the materials:

1. English Accents around the World.

2. Online Applications for Learning Pronunciation (Coniam [8])

3. Formal and Informal Speech

4. Pronouncing English Slang.

5. Lingking Sounds.

6. Vowels, Consonants and Diphthongs.

7. Phonetic Symbols.

From the classification, it can be taken into account that the students prefer to learn pronunciation that mostly deal with segmental and suprasegmental features of pronunciation. Furthermore, it is hoped that the findings from this point can be the basic data for the lecturer to design pronunciation materials.

\section{CONCLUSION}

Having analyzed the data from the questionnaire, it can be concluded that:

1. All of the students are in the possitive side dealing with the material given in pronunciation class. The following are the pronunciation materials that the participants agree to be maintained in learning English pronunciation:

a. Speech Organs Used in Pronouncing Words

b. Definition of English Sounds (Vowels, Diphthongs, Consonants)

c. How to Produce English Sounds (Vowels, Diphthongs and Consonants) by Using Phonemic Symbols

d. Minimal Pairs

e. Stress, Rising and Falling Intonation

f. Linking sounds, contracted forms, leaving out consonants, fast and careful speech, dividing speech into small units.

2. Related with the second point dealing with students' opinion about teaching and learning process, it can be sumed up that the students prefer to learn pronunciation through the following strategies or activities:

a. Reading words and sentences repeatedly.

b. Creating sentences and dialogues consisting of certain sounds being discussed and acting it out.

c. Listening to the English songs, watching videos used English language or completed with English subtitles, and imitating the pronunciation.

d. Looking up printed dictionary to check how to pronounce the words.

e. Interacting with native speakers directly.

3. The final point addressed in this study is related to students' prefferences toward pronunciation materials. It investigated, especially, students' expectation and want in line with pronunciation materials. From four closed statements on one open statement, it can be categorized the students' preference toward pronunciation materials. The following are the materials:

a. English Accents around the World. b. Online Applications for Learning Pronunciation

c. Formal and Informal Speech

d. Pronouncing English Slang.

e. Lingking Sounds.

f. Vowels, Consonants and Diphthongs.

g. Phonetic Symbols.

\section{REFERENCES}

[1] Kelly, Gerald. 2000. How to teach pronunciation. Oxford: Bluestone Press.

[2] Brown, James Dean. 1995. The Elements of Language Curriculum. Boston: Heinle \& Heinle Publishers.

[3] Tomlinson, Brian 2003. Developing Materials for Language Teaching. New York: Cromwell Press.

[4] Hancock, Mark. 1995. Pronunciation Games. Cambridge University Press.

[5] Hancock, Mark. 2004. English Pronunciation in Use. Cambridge University Press.

[6] Cheng, F. 1998. The Teaching of Pronunciation to Chinese Students of English. English Teaching Forum, January-March.

[7] Griffth, Carol \& Parr., M. Judy. 2001. Language Learning Strategies: theory and perception. ELT Journal Volume, 55, 250 - 251

[8] Coniam, D. 2002 Technology as an awarenessraising tool for sensitising teachers to features of stress and rhythm in English. Language Awareness, 11 . 